\title{
BACTERIOLOGICAL DIAGNOSIS OF TUBERCULOUS ENDOMETRITIS
}

\author{
BY \\ R. L. VOLLUM \\ From the Department of Bacteriology, Radcliffe Infirmary, Oxford
}

(RECEIVED FOR PUBLICATION FEBRUARY 3, 1954)

Ever since chemotherapy for tuberculosis became available endometrial tuberculosis has aroused increasing interest amongst gynaecologists. The diagnosis of this condition, and also the assessment of progress during therapy, depends largely on the pathological examination of curettings or biopsy specimens. The isolation and identification of the infecting organism provides definite confirmation of the diagnosis. Histology may provide strong presumptive evidence, but it cannot be as definite as positive bacteriological findings.

Haines (1952) has reviewed the literature on the subject and has pointed out some of the difficulties of pathological diagnosis. The continual renewal of the endometrium allows little time for extensive lesions to develop, and the amount of tuberculous tissue in a specimen obtained by biopsy or curettage may be limited and probably unevenly distributed in the material available for examination.

This report deals with the examination of 600 specimens taken by biopsy or curettage between August, 1950, and June, 1953. Of the 600 specimens, 436 were from patients in whom the diagnosis was not confirmed by the laboratory. One hundred and sixty-four were taken at various times from 42 patients in whom a diagnosis of tuberculous endometritis was established. Sixty-nine of these 164 specimens were found to be positive by one or more of the methods employed, and 95 were negative by all methods.

The number of specimens examined from the cases of endometrial tuberculosis varied from one to nine. Of the 42 patients, 27 each produced one positive specimen, and in 10 of these cases it was the only specimen examined. Two positive specimens were received from each of eight patients; three positive specimens from each of four patients; four positive specimens from one patient; and five positive specimens from each of two patients. The intervals between specimens were usually about three months.

\section{Technique}

The specimens were sent to the laboratory in normal saline. Each specimen was divided into two approximately equal parts, one part being used for histological examination, and the other for culture and guinea-pig inoculation.

\section{Histology}

The histological examinations were made by $\mathrm{Dr}$. A. H. T. Robb-Smith and Dr. R. H. Cowdell in the Department of Morbid Anatomy. Serial sections of the whole histological specimen were cut, and every fifth section was stained and examined. The histological diagnosis was based on the characteristic lesion and tissue reaction. No attempt was made to search for acid-fast organisms in the lesions.

\section{Culture and Guinea-pig Inoculation}

The other half of the specimen was ground in a Griffith tube with a volume of saline approximately equal to the volume of the specimen. Half of the resulting suspension, without further treatment, was injected subcutaneously into the thigh of a guinea-pig. The animals were tuberculin tested in the sixth week after inoculation, and were killed at the end of six weeks and examined for tuberculous lesions. In cases where the direct culture was negative, the organism was isolated from the guinea-pig lesions for sensitivity tests.

The remainder of the tissue suspension was mixed with an equal volume of $4 \% \mathrm{NaOH}$ in a universal container. It was kept at $37^{\circ} \mathrm{C}$. in the incubator for 30 minutes, and shaken at five-minute intervals. It was then diluted with five volumes of sterile distilled water and centrifuged at 3,000 r.p.m. for 30 minutes. The supernatant fluid was discarded. One drop of phenol red indicator solution was added to the sediment, and the mixture was brought to $p \mathrm{H} 7.4$ with dilute $\mathrm{HCl}$. Culture media were then inoculated with the deposit. The media in routine use were Löwenstein-Jensen and a modified Kirschner (Vollum, 1952). Dorset egg was also used in case any bovine strain should fail to grow on the glycerinated media. No strains were found which grew only on Dorset egg. All cultures were incubated at $37^{\circ} \mathrm{C}$. for six weeks, and were examined at weekly intervals. All cultures, whether obtained directly 
TABLE I

ANALYSIS OF THE RESULTS OF EXAMINATION OF 164 SPECIMENS OF ENDOMETRIUM OBTAINED BY BIOPSY OR CURETTAGE FROM 42 PATIENTS WITH PROVED TUBERCULOUS ENDOMETRITIS

\begin{tabular}{|c|c|c|c|c|c|c|c|c|c|c|c|c|c|c|c|c|}
\hline \multicolumn{2}{|l|}{$\begin{array}{l}\text { Method } \\
\text { of Examination }\end{array}$} & \multicolumn{14}{|c|}{$\begin{array}{l}\text { Combinations of } \\
\text { Negative and Positive Results }\end{array}$} & \multirow{2}{*}{\begin{tabular}{|c}
$\begin{array}{c}\text { Total of All } \\
\text { Positive Specimens }\end{array}$ \\
35 \\
40 \\
33 \\
24
\end{tabular}} \\
\hline $\begin{array}{l}\text { Histology . . inoculation } \\
\text { Guinea-pig } \\
\text { Kirschner culture } \quad \text {.. } \\
\text { Löwenstein-Jensen culture }\end{array}$ & $\begin{array}{l}\cdots \\
\cdots \\
\cdots\end{array}$ & $\begin{array}{l}+ \\
+ \\
+ \\
+\end{array}$ & $\begin{array}{l}+ \\
+ \\
+ \\
+\end{array}$ & $\begin{array}{l}0 \\
+ \\
+ \\
+\end{array}$ & $\begin{array}{l}+ \\
+ \\
+ \\
+\end{array}$ & $\begin{array}{l}+ \\
+ \\
0 \\
0\end{array}$ & $\begin{array}{l}0 \\
+ \\
+ \\
0\end{array}$ & $\begin{array}{l}0 \\
0 \\
+ \\
+\end{array}$ & $\begin{array}{l}+ \\
+ \\
+ \\
0\end{array}$ & $\begin{array}{r}0 \\
+ \\
0 \\
+\end{array}$ & $\begin{array}{l}+ \\
0 \\
0 \\
0\end{array}$ & $\begin{array}{l}0 \\
+ \\
0 \\
0\end{array}$ & $\begin{array}{l}0 \\
0 \\
+ \\
0\end{array}$ & $\begin{array}{l}\mathbf{0} \\
\mathbf{0} \\
\mathbf{0} \\
+\end{array}$ & $\begin{array}{l}\mathbf{0} \\
\mathbf{0} \\
\mathbf{0} \\
\mathbf{0}\end{array}$ & \\
\hline No. of specimens & $\ldots$ & 7 & 2 & 8 & 1 & 6 & 3 & 5 & 4 & 2 & 15 & 12 & 3 & 1 & 95 & 69 \\
\hline
\end{tabular}

or via the guinea-pig, were eugonic, and cultural characteristics were of the human type.

\section{Results}

Table I shows the various combinations of positive and negative results found in the 69 specimens which were positive by any of the four methods employed-histology, guinea-pig inoculation, Löwenstein-Jensen culture, and Kirschner culture. Only seven specimens were positive by all four methods. Guinea-pig inoculation gave slightly better results than other methods, with 40 out of 69 positive. Histology revealed 35 , Kirschner culture 33, and Löwenstein-Jensen culture 24. Löwenstein-Jensen medium failed in 12 specimens where the Kirschner medium was successful, and was positive in three specimens where the Kirschner medium was negative. The two culture media together revealed 36 of the 69 positives. Ninetyfive specimens were negative by all methods. The diagnosis was made on histology alone in 15 cases, on guinea-pig inoculation alone in 12 cases, and on culture alone in four cases.

The discrepancy between the four methods may be due to a number of factors, but probably chiefly to the small amount of tuberculous tissue and the small number and uneven distribution of viable tubercle bacilli in any specimen. If the whole of each specimen had been used for any one method, a higher percentage of positive results by that method might have been expected, but each method has certain disadvantages, and the risk of missing a positive finding is probably less by dividing the specimens and employing different methods.

Histology has the advantage of providing the result more quickly, but positive findings by guineapig inoculation or culture are more reliable.

\section{Summary}

Six hundred specimens of endometrial curettings or biopsy were examined for tuberculous infection by histology, guinea-pig inoculation, and culture. Sixty-nine of these specimens were found to be positive by one or more of these methods. Histology detected $51 \%$, guinea-pig inoculation $58 \%$, and culture $52 \%$.

No single method should be relied on for the diagnosis of tuberculous endometritis.

Mr. John Stallworthy kindly provided the majority of the specimens for examination.

I am indebted to Dr. A. H. T. Robb-Smith and Dr. R. H. Cowdell for the histological reports on these specimens.

\section{REFERENCES}

Haines, M. (1952). J. Obstet. Gynaec. Brit. Emp., 59, 721.

Vollum, R. L. (1952). Broadsheet No. 2, Association of Clinica Pathologists. 